\title{
DESAIN DAN IMPLEMENTASI APLIKASI UNTUK VISUALISASI INFORMASI PADA FILE OFFLINE LOG WEB SERVER
}

\author{
Agus Kurniawan \\ Fakultas Ilmu Komputer, Universitas Indonesia, Depok, Indonesia \\ agusk@cs.ui.ac.id
}

\begin{abstract}
Abstrak
Hampir sebagian besar web server mempunyai kemampuan untuk menghasilkan file log dalam format file text berbasis delimiter. File log ini dihasilkan setiap hari atau mingguan atau bulanan. Semakin banyak file log yang dihasilkan ini akan berdampak sulitnya dalam menganalisis file log tersebut sehingga diperlukan suatu tool berupa aplikasi yang dapat melakukan konsolidasi file log dan melakukan visualisasi informasi dari data yang terkandung didalam file log tersebut. Pada paper ini akan dipaparkan bagaimana mendesain dan mengimplementasi aplikasi yang dapat melakukan visualisasi pada file log web server.
\end{abstract}

Kata kunci : Data Visualization, Administration System

\section{Pendahuluan}

Perkembangan internet memicu pesatnya aplikasi web dengan berbagai corak dengan tujuan tertentu yang hendak dicapai. Web server yang berfungsi sebagai host dari semua aplikasi web mempunyai peran penting dalam hal ini.

Untuk memenuhi audit dan laporan, setiap web server umumnya menyediakan fitur yang dapat menulis file log setiap request dan response yang masuk kedalamnya. File log ini biasanya dibuat dalam interval harian, mingguan atau bulanan.

Seiring dengan lamanya operational web server maka file log yang dihasilkan juga semakin banyak. Hal ini akan menimbulkan masalah terutama dalam melakukan auditing atau membuat suatu laporan berdasarkan file log web server yang dihasilkan. Oleh karena itu, kita membutuhkan suatu tool yang dapat melakukan konsolidasi beberapa file $\log$ dan menampilkan visualisasi informasi berdasarkan data yang tersimpan pada file log tersebut.

\subsection{Tujuan}

Tujuan pembuatan aplikasi ini adalah mempermudah para administrator IT atau yang bertanggung jawab pada penanganan web server dalam menganalisa aktivitas web server pada log file.

\subsection{Ruang Lingkup} adalah

Batasan pada desain dan implementasi aplikasi
- Data log file berasal dari web server IIS (Internet Information Service) pada Windows Server 2003 dan Windows Server 2008

- Format data log file adalah W3C Extended

- Implementasi dengan memanfaatkan teknologi .NET

\section{Landasan Teori}

\subsection{File log Web Server}

Web server IIS mempunyai fitur untuk menulis data log file setiap ada request yang masuk ke web server yang dapat dijadwalkan sesuai dengan kebutuhan.

Web server IIS dapat menulis ke file log dengan tiga format yaitu [1]

- W3C Extended

- IIS log file format

- NCSA

Pada paper ini akan fokus ke format W3C Extended. Format file log W3C Extended adalah format file berbasis ASCII yang mempunyai banyak fitur sesuai dengan kebutuhan. Data yang ditulis pada file ini merupakan spaces delimiter. Sedangkan waktu yang tercatat tersimpan sebagai waktu UTC.

Fitur data yang sediakan oleh format file $\log$ W3C Extended antara lain:

- date. Menunjukkan tanggal terjadinya aktivitas $\log$ ini

- $\quad$ time. Menunjukkan jam terjadinya aktivitas log ini

- $\quad$ c-ip. IP address client yang melakukan request 
- cs-username. Nama yang melakukan authentikasi ke server

- s-sitename. Nama internet service dan nomor instance yang berjalan

- s-computername. Nama komputer server yang menulis file log ini

- $\quad$-ip. IP address server

- $\quad$ s-port. Port server yang digunakan

- cs-method. Metode akses yang dilakukan contohnya GET, POST

- cs-uri-stem. Target aksi

- cs-uri-query. Query yang dilakukan oleh client yang biasanya digunakan untuk dynamics page

- $\quad$ sc-status. Kode HTTP status

- $\quad$ sc-substatus. Kode error sub status yang telah terjadi

- $\quad$ sc-win32-status. Kode status Windows

- sc-bytes. Jumlah bytes yang dikirim oleh server

- cs-bytes. Jumlah bytes yang diterima oleh server

- time-taken. Lamanya waktu yang digunakan untuk mengeksekusi satu permintaan

- cs-version. Versi protokol HTTP atau FTP yang digunakan oleh client

- cs-host. Nama host header

- $\quad \operatorname{cs}$ (User-Agent). Tipe browser yang digunakan oleh client

- $\quad \operatorname{cs}($ Cookie). Isi cookie yang dikirim dan diterima

- $\quad \operatorname{cs}($ Referer). Site yang terakhir dikunjungi sebelum mengakses site yang sedang diakses

Masing-masing fitur data diatas akan ditulis oleh IIS apabila kita memasukkan (mengaktifkan) ke dalam daftar fitur data yang akan ditulis.

\subsection{Format File log}

Setiap file log yang dihasilkan oleh web server IIS akan berisi informasi berupa header dan data. Kadangkalanya satu file log akan mempunyai header yang berbeda-beda seperti ilustrasinya pada Gambar 1.

Header pada log file IIS diawal dengan tanda \# sedangkan datanya dengan space delimiter yang jumlahnya mengikuti header. Berikut ini contoh header dan data pada sebuah log file IIS.

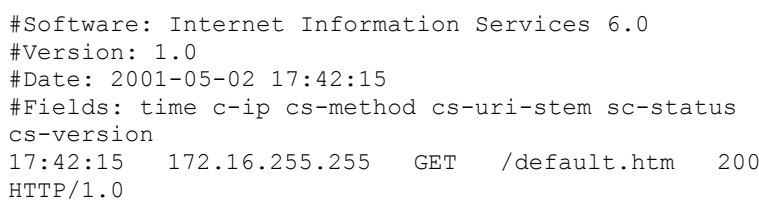

Pada umumnya header pada file log akan berisi informasi antara lain

- Software

- Version
- Date

- Fields

Informasi field yang digunakan dalam dilihat pada header dibagian \#Fields dan data file log akan mengikuti berdasarkan field yang digunakan.

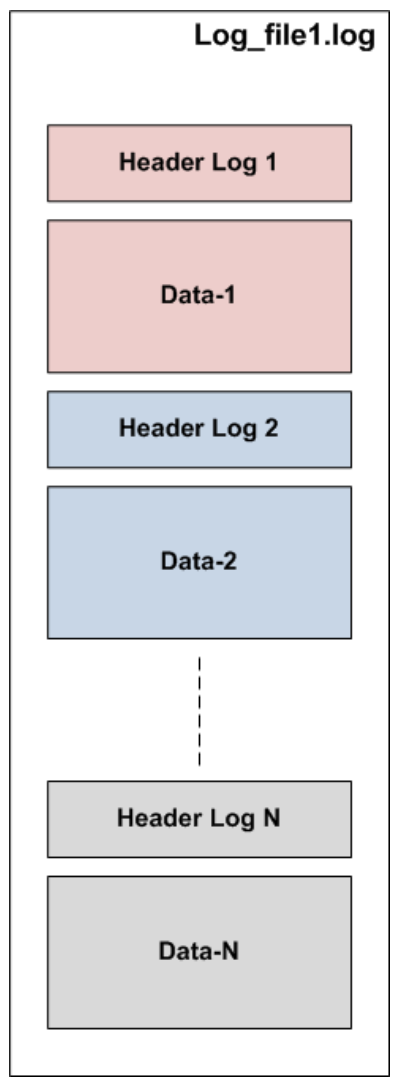

Gambar 1. Format header dan data log pada IIS

\subsection{Teknologi .NET}

.NET adalah framework platform yang dibuat oleh Microsoft. Tujuan utama dibuatnya framework ini memudahkan implementasi aplikasi baik desktop maupun web tanpa harus mengetahui banyak library/module pada OS Windows [2].

Di dalam .NET terdiri dari kumpulan library yang siap digunakan. Hasil kompilasi akan menghasilkan IL (Intermediate Language) sehingga dengan konsep ini maka .NET dapat support banyak bahasa pemrograman asalkan dapat menghasilkan IL sesuai standar.

\section{Desain dan Implementasi}

\subsection{Desain Umum}

Aplikasi ini didesain dengan pendekatan layering atau modular yang berbasis object-oriented sehingga diharapkan library atau modul dapat dipergunakan lagi (reusable) dan diperbarui sifatnya. Arsitektur 
aplikasi ini dapat dilihat pada Gambar 2.

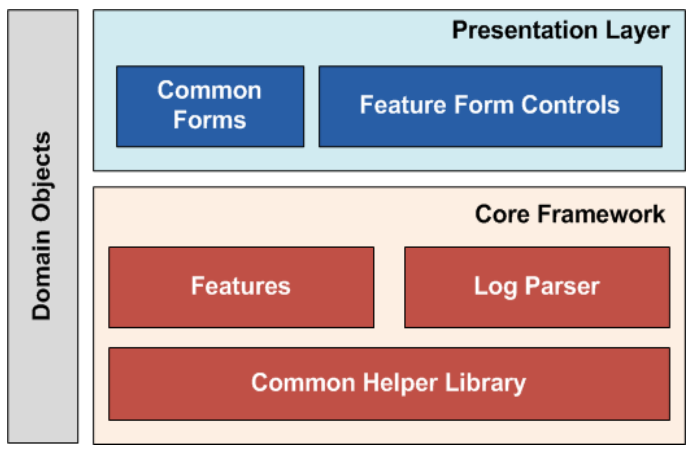

Gambar 2. Arsitektur umum aplikasi

Aplikasi ini secara arsitektur terbagi menjadi tiga bagian yaitu

- Core Framework

- Domain Objects

- Presentation Layers

Pembagian ini berdasarkan kesamaan fungsional masing-masing bagian.

\subsubsection{Core Framework}

Core Framework merupakan bagian terpenting aplikasi yang berfungsi sebagai parser dari sumber data log file. Di dalam modul ini terdapat tiga bagian yang didasarkan pada fungsinya. Tiga bagian ini yaitu

- Log Parser. Ini berfungsi sebagai parsing pada data log dari input $\log$ file.

- Features. Ini merupakan fitur visualisasi yang akan ditampilkan. Setiap fitur mempunyai karakteristik berbeda-beda.

- Common Helper Library. Fungsi umum yang dapat digunakan untuk membantu proses terjadi pada aplikasi ini.

Implementasi Log Parser dengan memanfaatkan Factory Method dan strategy patterns [3]. Diagram kelas dapat dilihat pada Gambar 3. Ada 4 objek penting dalam realisasi bagian Log Parser yaitu

- BaseLogParser. Objek ini berfungsi sebagai abstract object dan dapat diimplementasi sesuai dengan kebutuhan.

- W3cExtendedLogParser. Objek ini merupakan turunan dari objek BaseLogParser dimana didalamnya mengimplementasi parser untuk file log berformat W3C Extended.

- LogParserFactory. Objek ini adalah realisasi Factory Method [2] yang melakukan instansiasi objek BaseLogParser berdasarkan kondisi format file log.

- LogParser. Objek ini adalah composite object yang mana didalamnya terdapat objek BaseLogParser. Objek LogParser akan melakukan instansiasi objek BaseLogParser dengan instansiasi pada objek W3cExtendedLogParser.

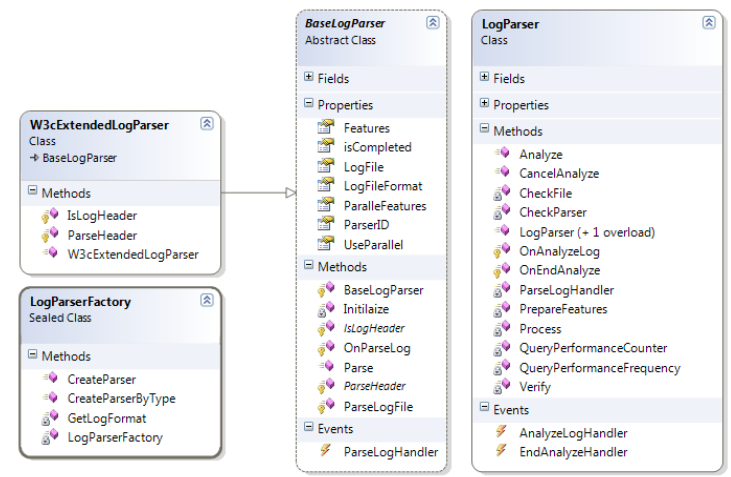

Gambar 3. Diagram kelas untuk Log Parser

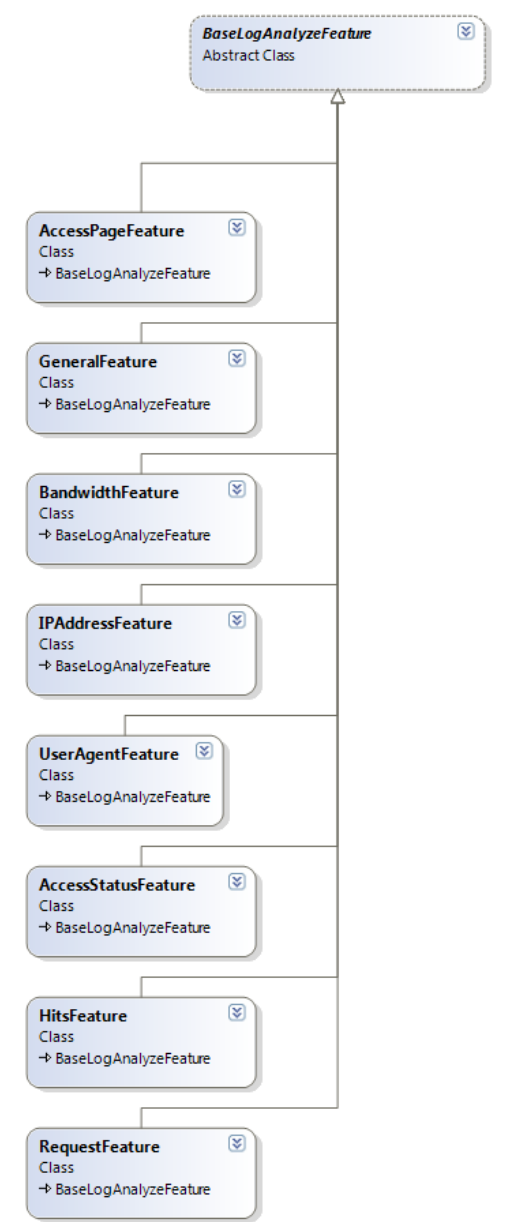

Gambar 4. Diagram kelas untuk feature

Teknik yang digunakan untuk mendeteksi apakah file log web server itu mempunyai format W3C Extended atau tidak adalah mendeteksi header yang dimiliki. Sesuai dengan standard format log W3C 
Extended, header yang dimiliki suatu file log akan diawali dengan \#. Oleh karena itu, algoritma paling mudah mendeteksi format file $\log$ W3C Extended adalah membaca header yang diawalnya adalah \#.

Informasi apa yang akan divisualisasikan didasarkan pada feature yang disediakan. Diagram kelas feature dapat dilihat pada Gambar 4. Semua objek feature merupakan turunan objek BaseLogAnalyzeFeature yang merupakan abstract object yang dapat dilihat pada Gambar 5. Pada implementasi disini, dibuat 8 feature yang merupakan turunan objek BaseLogAnalyzeFeature antara lain:

- AccessPageFeature

- AccessStatusFeature

- BandwidthFeature

- GeneralFeature

- HitsFeature

- IPAddressFeature

- RequestFeature

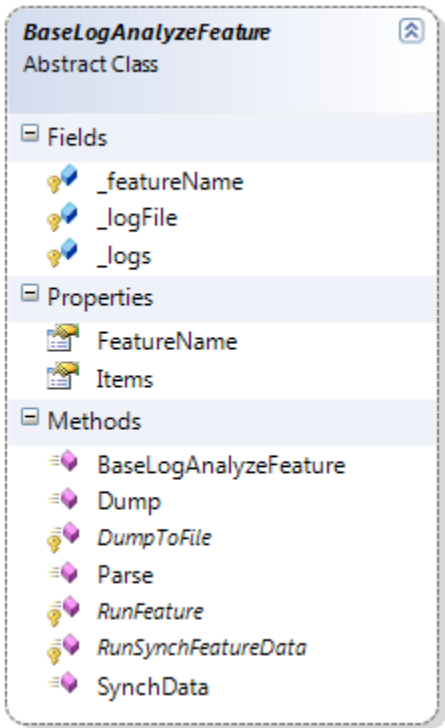

Gambar 5. Objek abstrak BaseLogAnalyzerFeature

\subsubsection{Domain Objects}

Domain Objects adalah value object yang menyimpan informasi dari data file log. Ini juga berfungsi sebagai Data Transfer Object (DTO).

Implementasi untuk aplikasi ini, objek domain akan menyimpan informasi yang berisi semua kolom sesuai format file log W3C Extended. Realisasi objek domain yaitu W3cExtendedLog yang dapat dilihat pada Gambar 6.

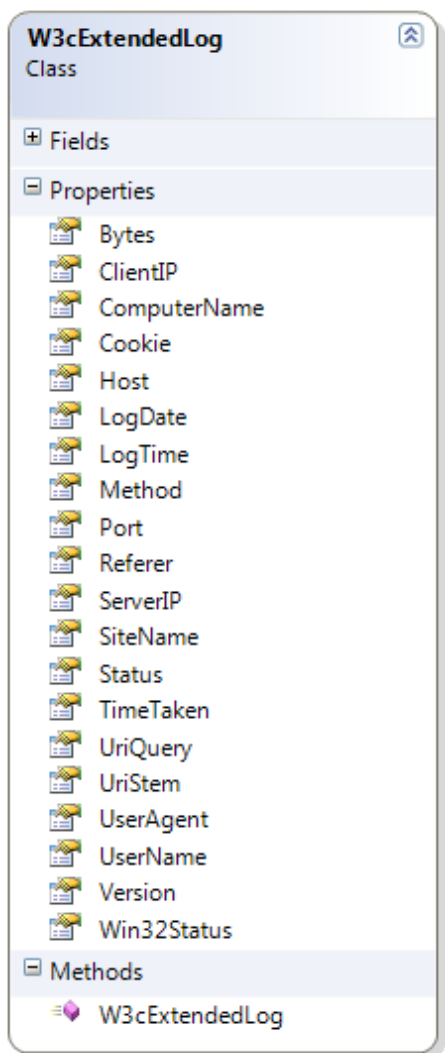

Gambar 6. Implementasi objek domain W3cExtendedLog

Objek W3cExtendedLog hanya mempunyai property (Set/Get Methods) dan tidak mempunyai behaviors atau method. Hal ini dikarena pada fungsinya sebagai domain objects yang hanya menyimpan data atau informasi.

\subsubsection{Presentation Layer}

Presentation Layer adalah Graphical User Interface (GUI) aplikasi yang akan dibuat. Pada layer ini terbagi menjadi dua bagian besar form yaitu

- Feature Form Control. Ini merupakan GUI yang dipergunakan oleh setiap untuk dilakukan visualisasi informasi

- Common Forms. Ini adalah GUI umum yang dapat dipergunakan oleh setiap objek.

Untuk mempermudah kontrol terhadap feature form control maka semua GUI form akan mengimplementasi Interface object yaitu BaseControl. Objek ini berisi property DataSource yang digunakan untuk pertukaran data dan sebuah methodlfunction yaitu Populate() yang berguna untuk melakukan populasi data ke GUI. Kelas diagram untuk feature form control dapat dilihat pada Gambar 7. Selain implementasi objek interface BaseControl, objek-objek feature form control juga merupakan 
turunan objek UserControl.

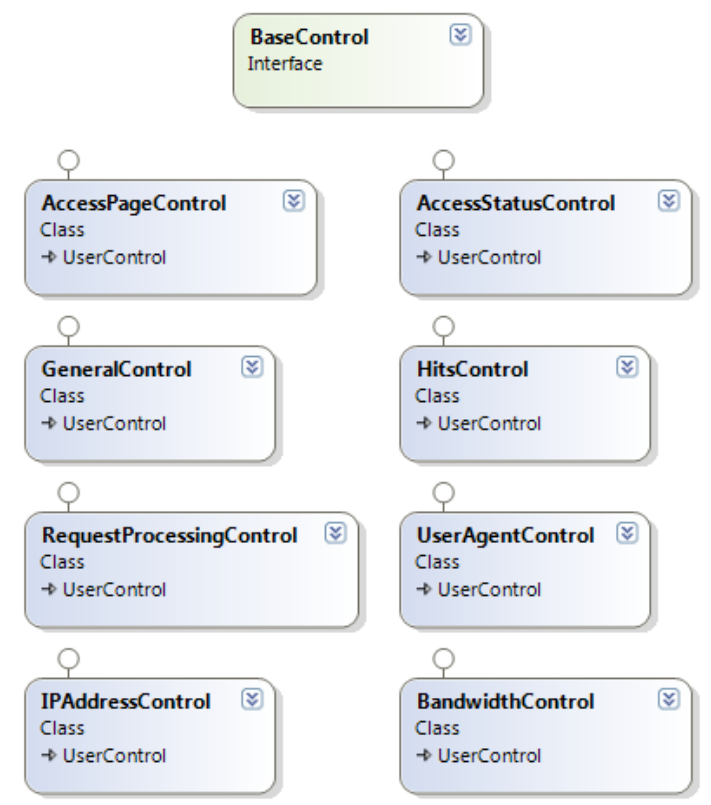

Gambar 7. Diagram kelas untuk feature form control

Common form disini digunakan sebagai container setiap konsolidasi file log yang akan telah diproses. Container yang dimaksud di sini yaitu objek WebLogUserControl yang merupakan turunan objek UserControl. Seperti yang diketahui, feature form control juga turunan objek UserControl sehingga cara menampilkannya cukup dengan menempelkan feature form control ke dalam WebLogUserControl.

\subsection{Algoritma}

Algoritma yang diterapkan untuk membaca file log dan selanjutnya melakukan parsing sesuai dengan kebutuhan Feature dapat dilihat pada Gambar 8.

Berikut ini algoritma yang diterapkan berdasarkan pada Gambar 8:

1. Mula-mula aplikasi mengidentifikasi jumlah file log dan menyimpan daftar nama file log tersebut

2. Masing-masing file log akan diterapkan proses seperti langkah 3 sampai 6

3. Isi data pada file dibaca setiap baris

4. Setiap data baris yang dibaca akan dilakukan deteksi apakah ini header atau data

5. Jika baris data itu adalah data maka akan dilakukan pemrosesan berdasarkan features yang ada

6. Jika selesai pembacaan datanya maka hasil pemrosesan akan dikonsolidasi

7. Apabila selesai semua proses pembacaan semua file maka akan diperoleh data konsolidasi berdasarkan feature-nya.

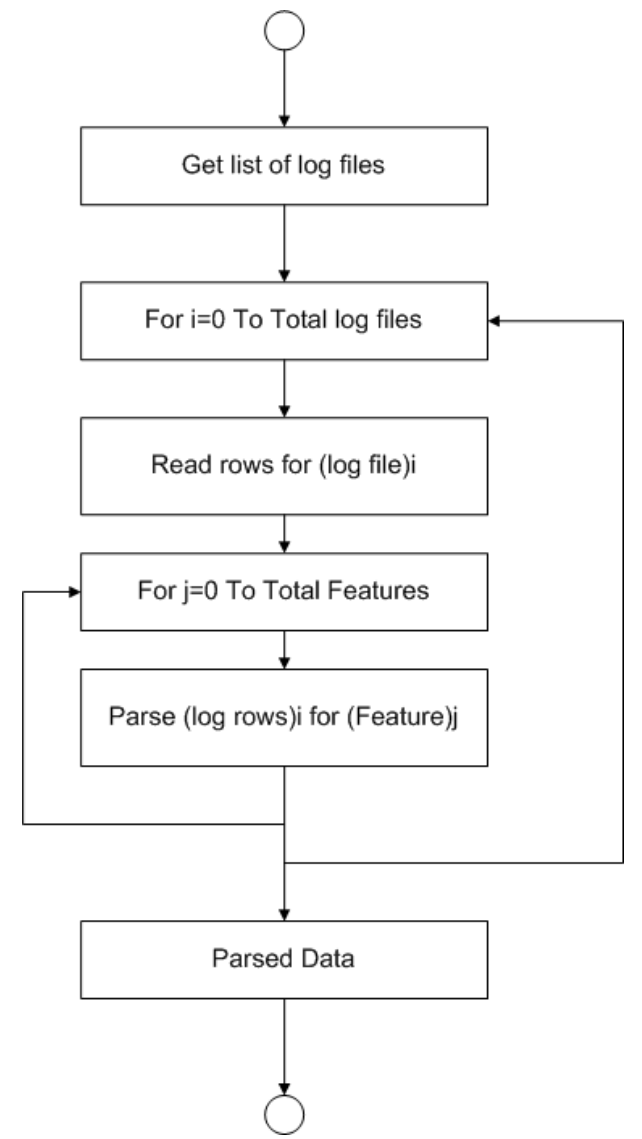

Gambar 8. Algoritma aplikasi visualisasi file log

8. Data konsolidasi ini yang akan ditampilkan pada GUI

\subsection{Visualisasi Informasi}

Visualisasi informasi pada aplikasi ini diwakili dengan Feature. Setiap Feature mempunyai cara memproses dan GUI untuk menampilkan data yang berbeda-beda

Pada aplikasi ini, ada 5 Feature yang akan diimplementasi antara lain:

1. Access Page. Visualisasi yang menggambarkan jumlah akses pada setiap halaman portal

2. Access Status. Visualisasi status pada setiap akses yang terjadi

3. Bandwidth. Visualisasi pemakaian bandwidth keluar masuk setiap akses

4. General. Informasi umum mengenai data file log yang telah diproses

5. Hits. Visualisasi jumlah akses terhadap waktu

6. IP Address. Visualisasi jumlah akses terhadap IP Address pengakses

7. Request. Visualisasi lamanya waktu pemrosesan setiap akses yang terjadi 


\subsection{Background Process}

Proses pembacaan beberapa file dan parsing data pada setiap file akan mempengaruhi interaktif aplikasi tersebut sehingga aplikasi terkesan seperti hang. Oleh karena itu, semua fase pemrosesan ini dilakukan dengan background process atau asynchronous.

Implementasi background process dilakukan dengan memanfaatkan sistem threading. Setiap pemrosesan akan dibuat satu thread dan apabila selesai maka thread ini akan memberitahukan ke aplikasi melalui pendekatan event driven [4].

\subsection{File log pada Remote Web Server}

Aplikasi ini tidak hanya dapat menerima input file log dari lokal web server tetapi juga dapat melakukan visualisasi file log pada remote web server.

Algoritma yang diimplementasi adalah mengcopy semua file log web server dari remote web server ke lokal mesin dimana aplikasi ini dijalankan. Untuk masalah sekuriti ketika melakukan koneksi dan meng-copy file log ke remote web server maka aplikasi melakukan impersonate dengan cara memberikan user dan password yang mempunyai hak pada remote web server.

\subsection{Konsolidasi Log File}

Aplikasi ini dapat melakukan konsolidasi beberapa file log web server untuk sekaligus dilakukan visualisasi informasi.

Pada Gambar 8 merupakan algoritma yang diterapkan pada aplikasi memungkinkan dalam melakukan konsolidasi karena aplikasi dapat menerima input beberapa file log sekaligus.

Acuan konsolidasi yang digunakan disini mengacu pada data date. Pada data baris yang mempunyai date yang sama akan dikelompokan menjadi satu grup data.

\subsection{Implementasi}

Implementasi aplikasi ini memanfaatkan teknologi .NET Framework dan development tool yang digunakan adalah Visual Studio 2008. Sedangkan source code ditulis dengan menggunakan bahasa Visual C\#. Hasil implementasi dapat dilihat pada Gambar 9.

Aplikasi ini juga dikompilasi pada dua target platform yaitu x86 dan x64. Ini dapat dilakukan melalui tool Visual Studio 2008.

Sumber kode aplikasi ini juga dipublikasikan sebagai open source project yang dapat diunduh di http://indihiang.codeplex.com .

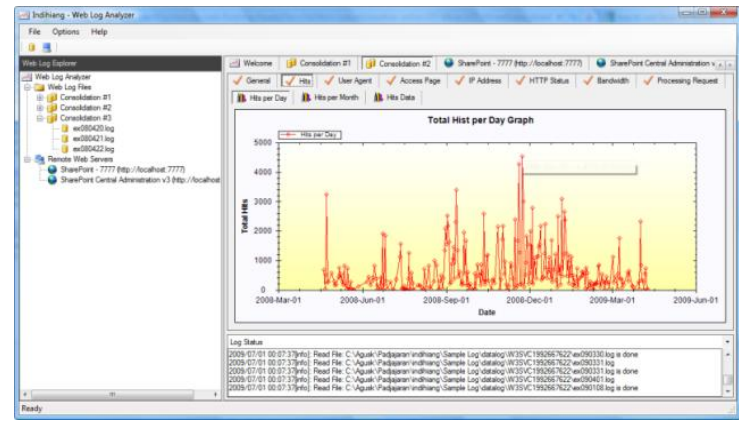

Gambar 9. Hasil implementasi aplikasi visualisasi file $\log$

\section{Penutup}

Pengujian aplikasi dengan menggunakan data file log yang diambil dari web server IIS dan diletakan di lokal mesin dimana aplikasi ini dijalankan. Selain itu, pengujian dilakukan dengan menggunakan file log pada remote web server.

Setelah memasukan satu file log atau beberapa kedalam aplikasi maka aplikasi ini akan bekerja untuk melakukan parsing dan menampilkan hasilnya dalam bentuk reporting. Contoh beberapa reporting yang dihasilkan aplikasi ini dapat dillihat pada Gambar 10a-10h.

\section{REFERENSI}

[1] Microsoft, IIS Log File Formats, http://www.microsoft.com/technet/prodtech nol/WindowsServer2003/Library/IIS/be22e 074-72f8-46da-bb7ee27877c85bca.mspx?mfr=true.

[2] Microsoft .NET Framework, http://www.microsoft.com/net.

[3] Erich Gamma, Richard Helm, Ralph Johnson and John Vlissides, AddisonWesley Professional, 1994.

[4] Gregor Hohpe and Bobby Woolf, Enterprise Integration Patterns, AddisonWesley, 2003. 


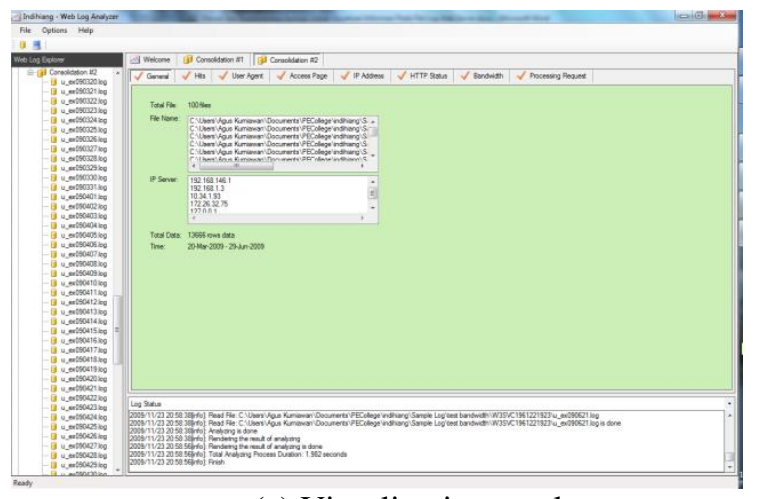

(a) Visualisasi general

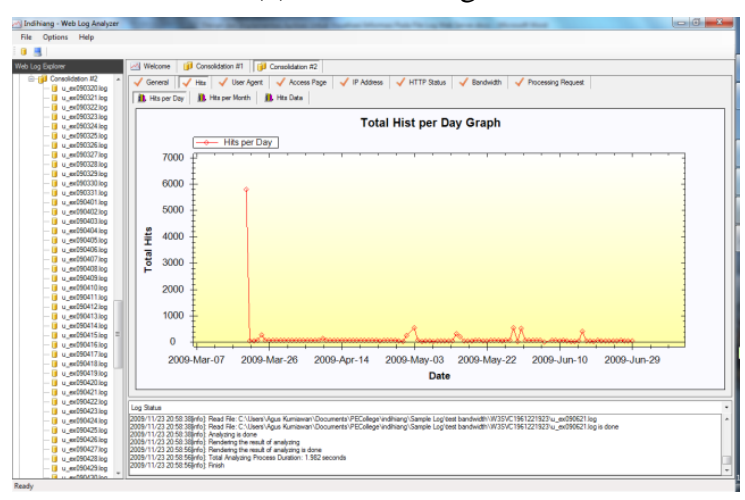

(b) Visualisasi hits

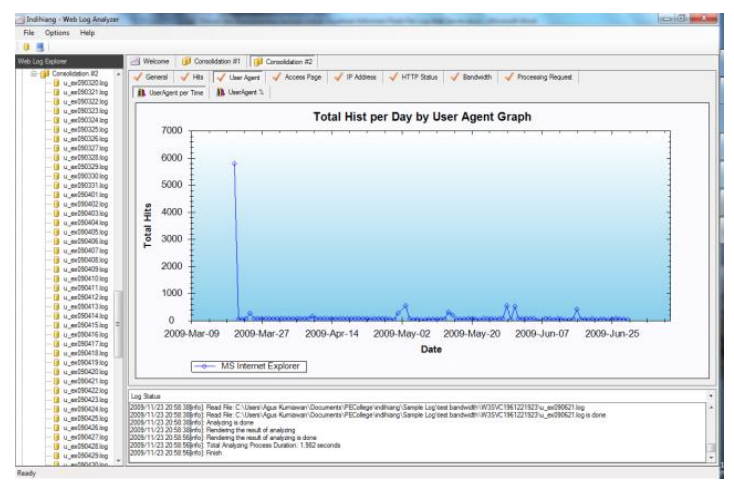

(c) Visualisasi user agent

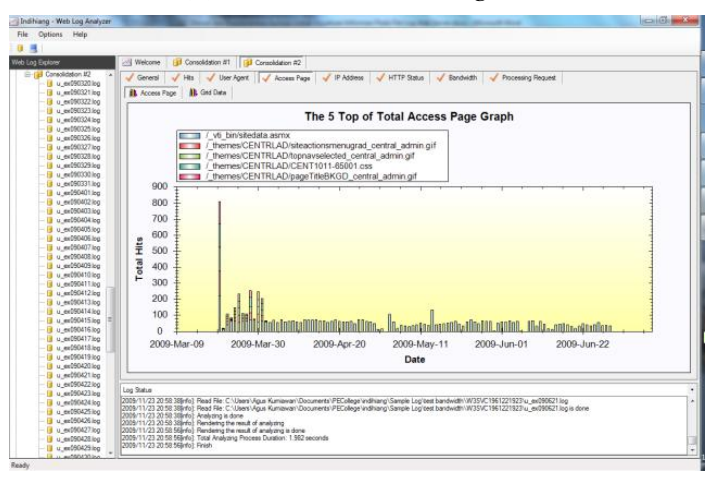

(d) Visualisasi access page

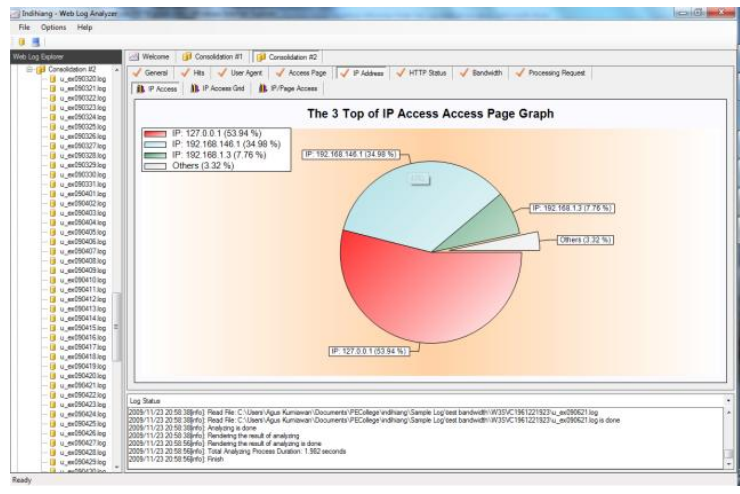

(e) Visualiasi akses terhadap IP address

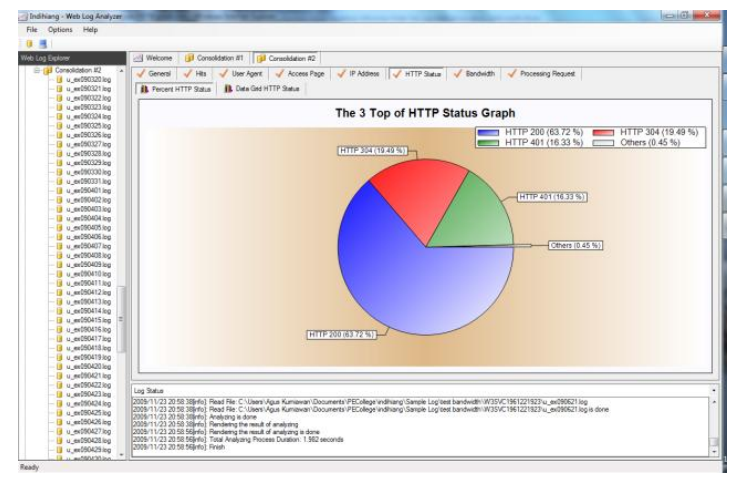

(f) Visualisasi HTTP status

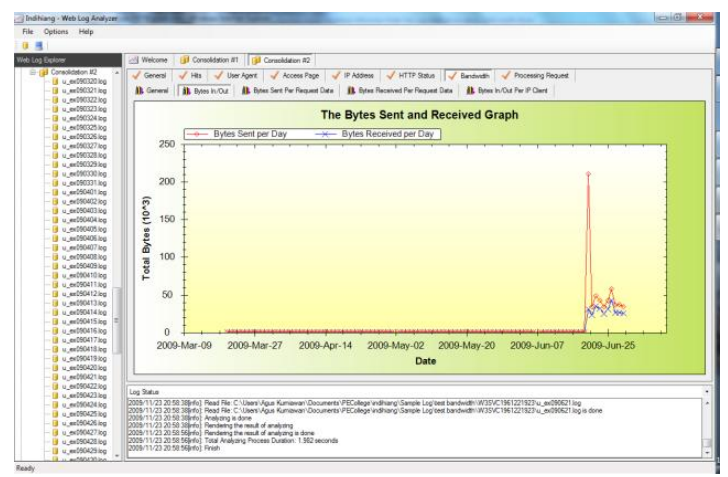

(g) Visualisasi penggunaan bandwidth

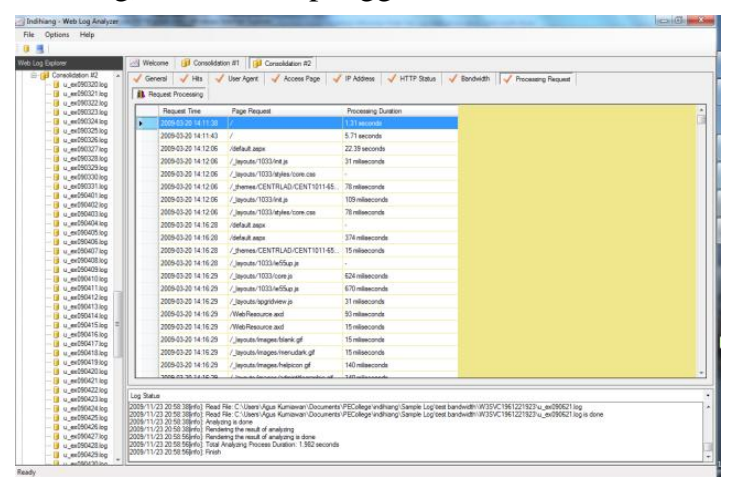

(h) Visualisasi lamanya proses

Gambar 10a-10h. Contoh hasil visualisasi pada beberapa log file 